\title{
IT-RELATED CHALLENGES FACING THE BULGARIAN ARMED FORCES AND THEIR PERFORMANCE RELATED IMPACT
}

\author{
Atanas ZAPRIANOV
}

\section{Bulgaria and NATO membership}

Bulgaria is one of the South-Eastern European countries that declared its willingness to joint NATO four years ago. In April 1997, with full consensus the National Assembly (the Bulgarian one-chamber Parliament) formally approved this political decision. As a result, many political, and legislative initiatives, as well as defense reform decisions have being taken by the Government since. The Bulgarian Armed Forces modernization was predetermined by NATO's requirements for operational interoperability with the Allied Forces. Implementation of NATO's standards became very important for the achievement of the political goals. According to the Bulgarian Membership Action Plan, which is coordinated with NATO, Bulgaria has to fulfill 82 preparation objectives, called Partnership Goals. More than a quarter of them are either directly or indirectly related to the command, control, communications and computer (C4) systems. In this way, the modernization of the Bulgarian Armed Forces creates a new information environment in which the Chief Information Officer of the Ministry of Defense performs its functions. The most pressing information technology-related challenge facing the Bulgarian Armed Forces is implementing an IP router-based network, which depends on information technology policy for modernization of defense policy, doctrines, staff's structures, command and control, and communications and information systems. Advanced information technologies can greatly increase the amount of useful knowledge available to our military organizations and improve their ability to put that knowledge to constructive use with the Allied Forces. Combining these technologies with appropriately conceived defense policy, doctrines and organizational design of the staff will provide the required interoperability. 


\section{Political environment}

The first challenge of the modernization is to change defense policy. Because of its political nature policy development is an important imperative for the Chief Information Officer of the Bulgarian Armed Forces (BAF). Defense policy development is a long-term process. According to article 3(1) of The Bulgarian Law on Defense and Armed Forces "Defense is a system of activities for strengthening peace and security for preserving national values and for maintaining the Armed Forces, economy and population in readiness for actions, as well as activities in case of crisis or war." 1 Defense policy influences the information environment of the Armed Forces by helping to achieve an effective management of resources. The new defense policy also has to reflect fundamental changes, in conceptual and practical aspects of defense, as well as the reasons behind these changes. The cornerstone of the new defense policy is democratic control and civilian leadership over the Bulgarian Armed Forces. ${ }^{2}$

Along with our firmly stated willingness for NATO membership, policy makers must be concerned about present and future threats to national security, and the need to provide adequate military power to meet these threats. ${ }^{3}$ The lessons learned from past reforms show that these radical steps are completely justified. Changes in military structures are very difficult to make. A joint Bulgarian and USA team conducted a study to assess the Armed Forces' reforms. Its main conclusion was that the plan we had followed until 1999 did not fit the Bulgarian strategic environment, political priorities and integration issues. ${ }^{4}$

A key point now is to determine measurable parameters for Armed Forces reduction, and to define proper approaches to speed up the reform. Attention is focused on the resources required to create an active force of 45,000 military personnel. In order to achieve the goals of defense policy the Government issued a program called "Bulgaria 2001", that defines the priorities as follows: building up the new model of national security and defense; creating a legislative basis adequate for a democratic society; focusing efforts on development of efficient rapid reaction forces as a part of the Bulgarian Armed Forces; defining Bulgarian's military contributions to the international community, and gradually implementing activities in accordance with The Bulgarian Membership Accession Plan to NATO. ${ }^{5}$

\section{Doctrinal environment}

The second challenge is to provide a conceptual and doctrinal framework for modernization. This framework is a collection of many documents, the most important of which are: The National Security Concept, The Military Doctrine, and the operational Doctrines of the Land Forces, the Air Forces and the Navy. In 
addition to these there are tactical doctrines, regulations, orders, governmental decisions, decisions and orders of the Minister of Defense, etc. While all these documents are important, I will focus on the first two documents.

The National Assembly of Bulgaria has approved the National Concept of Security ${ }^{6}$ as a basic conceptual document that defines political objectives, principles, and approaches to strengthen the security and defense of the country. The National Concept of Security formulates our country's policy on equal ground common with the policy of other democracies and speeds up the preparation for NATO and European Union membership. It identifies the Armed Forces as providing for the national security and required the government to acquire the necessary resources for their mission. It is the responsibility of the government to provide stable and strong law for security, and policies for motivating military personal and creating reliable information support. Article 42 of the concept defines how important the information environment is for national security, stating, "Information guarantees national security, protecting constitutional rights and freedom of citizens, by collecting, processing and disseminating correct public and private information through advanced development of the national communications and media. It is a top priority to establish a special law for protection of public and private information resources."

The Military Doctrine ${ }^{7}$ is the second important document for defense modernization. This document plays a key role for the implementation of an advanced information technology for modernization of the Armed Forces. According to the Military Doctrine, defense policy has to establish a military and strategic environment that allows the Bulgarian state to obtain necessary defense resources and potential to balance any threats. Furthermore, article 26 of the Military Doctrine shows that "Bulgaria comprehends NATO and European Union membership as a possibility, to share responsibilities with democratic countries for protection of common values."

The government, in accordance to the Military Doctrine, assumes its responsibility to define the place, the role and main functions of the Armed Forces in implementing the European democratic principles. Also government has to evaluate features of military strategic environment that are essential for building up national security. It is the government's obligation to define national goals and priorities in the sphere of defense policy. In addition, the government is authorized to choose directions towards building adequate military power that complies with current political realities and requirements.

The implementation of advanced information technology will help establish a system to measure the progress of reformation of the Bulgarian Armed Forces and their formation as an effective power with preventive potential, interoperable with NATO's defense system. Such technology will allow participation in peacetime 
cooperation, and coordination in time of crises management and in case of military conflict. ${ }^{8}$

\section{Organizational changes}

From a practical point of view, many military leaders have a great willingness to use information technology to overcome difficulties caused by force reduction. Because of that, the next challenge for implementation of information technology is staff structure design. The first steps have been taken since the plan for reorganization was approved in 1999. In place of the former Warsaw Pact staff organization, related to the field army-division structures, we established the corps-brigade structure with NATO's staff organization.

The General Staff of the Bulgarian Armed Forces and the staff headquarters of the services were reduced more than 50 percent. The General Staff now has as follows: Personnel directorate, Intelligence directorate, Operational directorate, Logistic directorate, Defense and armed forces planning directorate and Communications and information systems directorate. Similarly, staffs below have been reorganized. They are not ready to operate in NATO environment until knowledge of NATO information procedures is obtained.

We must meet the challenges of implementing advanced technology in our command and control system during the modernization phase. ${ }^{9}$ Actually, information flows were changed, but methods, procedures, applications and content are still obsolete. Furthermore, many officers are not prepared well to use advanced information systems for their job performance. Operational architecture design of command and control systems became a priority for the Chief information officer. It requires: forming teams from different branches; providing deep analyses of future warfare; learning from NATO's experience; training officers and using computer simulation models. Undoubtedly this process will be very difficult. Employing an evolutionary development and acquisition paradigm for implementing command and control capabilities will minimize the operational and cost risks associated with system implementation and will also ensure that an effective core capability will be realized in a timely manner.

\section{Technology environment ${ }^{10}$}

A system for high speed, reliable communications is perhaps the key enabler for realizing the full potential of future organizations that have to be established during the modernization. A high-speed strategic communications system, with reliable connectivity and robust tactical communications will be essential to network dispersed organizations and distributed but cooperative or joint operations. Some of 
the challenges to the strategic systems, connectivity and tactical system for one brigade include the ability to rapidly move over all territory of the country, carry large volumes of traffic and support to NATO.

Parts of the solution are found in ongoing projects for modernization of our communications infrastructure. A responsive and secure communications network must be developed to link the military headquarters across all levels of command. This is an essential enabling capability, of highest priority, to permit the National Command Authority and its associated chain of command, to effectively control all national military forces in the application of military power to achieve national objectives. Hence, in its fundamental form, the communications network must be able to support the timely transmission of orders and directives from higher headquarters to all subordinate forces, and be able to facilitate the timely receipt of reports, from all subordinate headquarters of the constituted military forces structure. Together, these enable the headquarters in the chain of command to monitor and control authorized military operations. To ensure timely information exchange, both secure voice service and a secure TCP/IP router-based data transmission network is required.

An advanced information system is also required at each command headquarters to provide timely and effective analytic support to the commander and his specialist functional area. Such system must enable intelligent decision-making across the entire spectrum of "informational", "organizational", and "operational" decisions. This can best be accomplished by information subsystems, organized along functional area specialists lines, which include appropriate databases and decision support tools necessary to enable the specialist staffs to accomplish their work in a timely and competent manner.

\section{Conclusion}

In conclusion, implementation of an advanced information technology for modernization of all infrastructures of the Bulgarian Armed Forces is essential. It strongly affects defense policy, doctrines, organizations and command, control, communications and information systems. In addition, it is required to support Bulgarian government speeding up priorities in military reform in order to achieve the political goal of NATO membership. Information technology will be critical because modernization over the next year is crucial for Bulgaria to be timely prepared for the second wave of NATO's enlargement. 


\section{Notes:}

1 Law on Defense and the Armed Forces of Republic of Bulgaria, State Newspaper, no. 112, 1995.

2 For the status of civilian and democratic control over the Bulgarian Armed forces refer to Plamen Pantev, Valeri Ratchev and Todor Tagarev, "Civil-Military Relations in Bulgaria: Aspects, Factors, Problems," in Civil-Military Relations in South-East Europe: National Perspectives and PfP Standards, ed. Plamen Pantev (Vienna, Institut fuer Internationale Friedenssicherung, 2001), pp. 31-62.

The two major national documents that treat these issues are the National Security Concept and the Military Doctrine of the Republic of Bulgaria. Although recent, they are under intensive debate after the September $11^{\text {th }}$ terrorist acts and the subsequent biological attacks against civilians.

4 Bulgarian Defense Reform Study, Final Report (Washington, DC: The Office of the Assistant Secretary of Defense for International Security Affairs and U.S. EUCOM, July 1999).

Cornerstones of Bulgarian Security and Defence Policy, ed. Velizar Shalamanov (Sofia: Ministry of Defence, July 2001).

National Security Concept of the Republic of Bulgaria, State Newspaper, \# 46 (22 April 1998). Available full text in English at http://www.md.government.bg.

Military Doctrine of the Republic of Bulgaria, Approved by the XXXVIII National Assembly of the Republic of Bulgaria on April 8, 1999, (Sofia: Military Publishing House, 1999). Full text in English is available at http://www.md.government.bg.

For details refer to Miho Mihov, "The Bulgarian Armed Forces in the Information Society," Information \& Security: An International Journal 1, 1 (Summer 1998), 15-25; Velizar Shalamanov and Todor Tagarev, Information Aspects of Security, foreword by General Miho Mihov (Sofia: ProCon, 1996).

With the start of defense reform Bulgaria, jointly with US, conducted a comprehensive C4 Study: Command, Control, Communications and Computers Study for Bulgaria (MITRE, January 2000). It was followed by the adoption of the following documents: Main Recommendations for the development of C4I Systems (Sofia: Ministry of Defense, May 2000) and Manual for C4I Life Cycle Management in the Ministry of Defense and the Bulgarian Armed Forces (Sofia: Military Publishing House, 2000). The latter provided for institutionalizing the Chief Information Officer.

Decisions in this area are influenced by theoretical developments and the experience of Bulgaria's strategic partners, most notably the United States. See for example Loren Diedrichsen, "Command \& Control: Operational Requirements and System 
Implementation," Information \& Security: An International Journal 5 (2000), 23-40; Charles Myer, "C4ISR Architectural Frameworks in Coalition Environments," Information \& Security: An International Journal 5 (2000), 60-72; Roland J. Ronald, "Applying Modeling and Simulation to Enhance National and Multi-National Cooperation," Information \& Security, vol. 3 (1999), pp. 12-24.

Major-General ATANAS ZAPRIANOV is Head of the Communications and Information Systems Directorate of the General Staff of the Bulgarian Armed Forces and Chief Information Officer of the Ministry of Defense. He was appointed to this position after distinguished service in the Land Forces and on joint positions. Major-General Zaprianov holds a M.Sc. degree in Communications Technology from the Bulgarian Army Academy, Veliko Tyrnovo. $\mathrm{He}$ is a graduate the "G.S. Rakovsky" Defense and Staff College in Sofia with a Masters degree in Military Art. In 1996 he graduated with distinction the Senior Officers' Course at the same College. Currently, General Zaprianov is taking senior executive course at IRMC at the National Defense University, Washington, DC. He is member of the Interagency Committee on Development of the Information Society and of the Armed Forces Communications and Electronics Association. Major-General Atanas Zaprianov is frequently keynote speaker to events organized by AFCEA Bulgarian Chapters, as well as to other professional conferences and seminars. 